\title{
INVESTIGATION OF THE EFFECT OF HOLDING TIME AND MELT STIRRING ON THE GRAIN REFINEMENT OF AN A206 ALLOY
}

\author{
PREISKAVA VPLIVA ČASA ZADRŽEVANJA IN MEŠANJA TALINE \\ NA ZMANJŠANJE VELIKOSTI ZRN ZLITINE A206
}

\author{
Neşet Akar ${ }^{1}$, Ziya Tanyel ${ }^{3}$, Kadir Kocatepe ${ }^{1}$, Ramazan Kayikci ${ }^{2}$ \\ ${ }^{1}$ Gazi University, Department of Metallurgical and Materials Engineering, Ankara, Turkey \\ ${ }^{2}$ Sakarya University, Department of Metallurgical and Materials Engineering, Sakarya, Turkey \\ ${ }^{3}$ Gazi University, Graduate School of Natural and Applied Sciences, Ankara, Turkey \\ rkayikci@sakarya.edu.tr
}

Prejem rokopisa - received: 2014-12-12; sprejem za objavo - accepted for publication: 2015-06-17

doi:10.17222/mit.2014.302

\begin{abstract}
Effects of melt stirring and holding time were studied with an Al-4.5\% of mass fractions of $\mathrm{Cu}$ (A206) alloy. The optimum level of a grain refiner was determined in conjunction with both continuously stirred and non-stirred melts during the holding time. Results showed that a mass fraction of a Ti addition of as low as $0.03 \%$ was sufficient to obtain the $82 \mu \mathrm{m}$ average grain size, while a Ti addition exceeding the mass fraction of $0.03 \%$ showed no significant effect on the grain size of castings. The grain refinement tends to fade with a long holding time in a non-stirred liquid. The results also showed that an effective grain refinement of the A206 alloy can be achieved with a long holding time as long as the liquid alloy is continually stirred.

Keywords: grain refinement, melt stirring, holding time, Al-4.5Cu alloy, A206 alloy
\end{abstract}

Raziskan je bil vpliv mešanja in časa zadrževanja taline zlitine Al-4,5 \% masnega deleža Cu (A206). Določena je bila optimalna količina udrobnjevalca zrn, v povezavi s stalnim mešanjem ali brez mešanja taline med zadrževanjem. Rezultati so pokazali, da je bilo že $0,03 \%$ masnega deleža dodatka Ti, dovolj za doseganje povprečne velikosti zrn $82 \mu \mathrm{m}$, medtem ko dodatek Ti večji od $0,03 \%$ masnega deleža, ni pokazal vpliva na velikost zrn ulitkov. Učinkovitost drobnjenja zrn se zmanjša pri dolgih časih zadržanja in brez mešanja taline. Rezultati so pokazali še, da je mogoče doseči učinkovito drobnjenje zrn tudi pri dolgih časih zadrževanja, dokler se talina stalno meša.

Ključne besede: drobnjenje zrn, mešanje taline, čas zadrževanja, zlitina $\mathrm{Al}-4.5 \mathrm{Cu}$, zlitina $\mathrm{A} 206$

\section{INTRODUCTION}

$\mathrm{Al}-\mathrm{Cu}$ alloys are one of the most important Al-based alloys because they provide good castability and excellent mechanical properties. ${ }^{1-6}$ Due to their superior mechanical properties, $\mathrm{Al}-\mathrm{Cu}$ alloys can be used in many areas such as aircraft construction, military field and automobile manufacturing. ${ }^{4}$ Grain refinement of $\mathrm{Al}-\mathrm{Cu}$ alloys significantly improves the microstructure and mechanical properties. ${ }^{7-9}$ Along with many advantages, hot tearing, which frequently occurs during solidification due to a long freezing range, is a severe problem in producing cast components with these alloys. Previous works on casting and solidification of $\mathrm{Al}-\mathrm{Cu}$ alloys consistently indicated that hot tearing can be eliminated with a good grain refinement. ${ }^{1-4,7-9}$ Grain refinement was also found to be effective for reducing the amount of the porosity and size of the pores, and improving the feeding of cast $\mathrm{Al}-\mathrm{Cu}$ alloys. ${ }^{9}$ Titanium and boron are added in the form of Al-Ti-B master-alloy rods to cast aluminium alloys for the grain refinement. Rod-type additions were found to be more effective for providing, controlling and optimizing $\mathrm{TiB}_{2}$ particles than the salt form. ${ }^{10,11}$ It was reported in recent years that $\mathrm{Al}-\mathrm{Ti}-\mathrm{C}$ master alloys are also effective grain refiners. ${ }^{4,12}$ Due to its high refining potential, an A15Ti1B alloy in the rod form is one of the most commonly used grain refiner and has been widely accepted in controlling the grain size and microstructures of aluminium alloys in industrial applications. ${ }^{13}$

The A206 alloy is a well-known Al-Cu casting alloy and a research on grain refinement with this alloy indicated that a proper grain refinement can be achieved with a $0.15-0.30 \%$ titanium mass fraction of the final cast part. ${ }^{14}$ On the contrary, in recent years other researchers $^{3,5,7-9}$ showed that modern grain refiners containing $\mathrm{Al}-\mathrm{Ti}$ and $\mathrm{B}$ are more suitable for an acceptable grain refinement of A206 alloys if the Ti content is lower than $0.15 \%$.

Despite a number of studies conducted in the past to investigate the grain refinement of $\mathrm{Al}-\mathrm{Cu}$ alloys, ${ }^{3,5-9,12,15-16}$ studies on the effects of the holding time and melt stirring on the grain-refinement process have not been published. Therefore, in this work, the optimum amount of the grain refiner for the A206 alloy, using an Al5Ti1B rod-shape grain refiner, in combination with the holding time and melt stirring, was studied. 


\section{EXPERIMENTAL PROCEDURES}

A206 alloys with two different chemical compositions were prepared using commercial-purity $\mathrm{Al}$ ingots and commercially pure $\mathrm{Cu}$ wires in a new $\mathrm{SiC}$ crucible. The final chemical compositions of these alloys before the grain-refiner additions are given in Table 1. A Spectro-type optical spectrometer was employed to perform a chemical analysis of the alloys throughout this study. An industrial electrical-resistance furnace with a $600 \mathrm{~kg}$ capacity and a $\mathrm{SiC}$ crucible were used for the melting.

An A15Ti1B master alloy was introduced into the liquid A206 alloy at $730{ }^{\circ} \mathrm{C}$ followed by rotary degassing for 10 min with dry argon. The temperature of the liquid metal in the melting furnace was continuously controlled with a K-type thermocouple connected to the control unit of the furnace to ensure the holding of the liquid at $730{ }^{\circ} \mathrm{C}$.

Grain-refining experiments were carried out using the Alcan standard grain-refining test ${ }^{10}$ with two sets of samples. In the first set of experiments, samples were taken from the crucible at $730^{\circ} \mathrm{C}$, before the grain-refiner addition. Samples were also taken after each addition of the Al5Ti1B rod-type master alloy introducing (0.01, $0.02,0.03,0.05,0.1,0.2,0.3) \% \mathrm{Ti}$ contents into the liquid alloy. After each addition, the liquid alloy was redegassed for $10 \mathrm{~min}$ at $730{ }^{\circ} \mathrm{C}$. This resulted in 10 -min intervals between the sample-taking processes.

The second set of experiments was carried out to determine the effects of the holding time coupled with melt stirring on the grain refinement. To implement this, a new heat of the A206 alloy was melted in a new crucible and heated up to $730{ }^{\circ} \mathrm{C}$. The Al5Ti1B master alloy was introduced into the melt to obtain a $0.05 \% \mathrm{Ti}$ content within the alloy. After a 10-min degassing treatment, the purging argon was turned off and the molten alloy was continuously stirred using the graphite lance of the rotary degassing unit with a rotating speed of $150 \mathrm{~min}^{-1}$ for $90 \mathrm{~min}$. Samples for the Alcan grain-refining tests were taken during the whole stirring period, in 30-min intervals from the beginning to the end.

Finally, the melt was re-degassed for $10 \mathrm{~min}$ and held for another $90 \mathrm{~min}$ without any stirring actions. During this second 90-min period, Alcan test samples were also
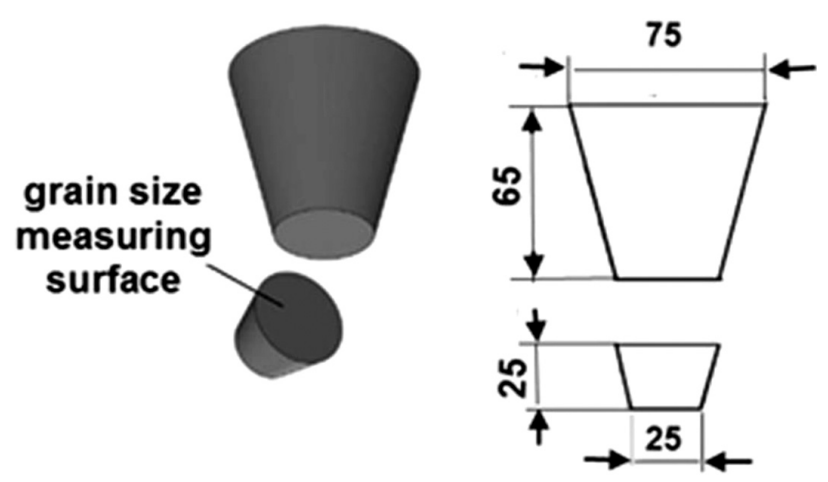

Figure 1: Alcan test dimensions and grain-size measuring surface Slika 1: Dimenzije Alcan preizkušanca in površina za merjenje velikosti zrn

taken in 30-min intervals, in the same manner as explained above. At the end of this period, the melt was re-stirred for only $1 \mathrm{~min}$ and the final sample was taken.

The specimens for the metallographic examinations were cut as shown in Figure 1. The surface of each specimen was electro-polished using $5 \mathrm{~mL}$ of $\mathrm{HClO}_{4}$, $15 \mathrm{~mL}$ of 2-Butoxyethanol, $60 \mathrm{~mL}$ of ethanol and $20 \mathrm{~mL}$ of distilled water. The average grain size was determined with the linear intercept method according to the ASTM E112 standard, at different regions of each sample.

\section{RESULTS AND DISCUSSION}

\subsection{Grain-size measurements}

The mean values of the measured grain sizes with various Ti contents are shown in Table 2, which indicates that the titanium contents in the alloy were determined within a narrow variance. Table 2 also shows that the grain size of the samples decreased dramatically with the addition of the Al5Ti1B master alloy regardless of the titanium content. The average grain size versus the $\mathrm{Ti}$ content is also shown in Figure 2. Figure 2 indicates that the addition of the grain refiner, even with a Ti content as low as $0.01 \%$, resulted in a remarkable reduction in the grain size of the alloy. Figure 2 also indicates that the lowest grain size of the alloy is about $80 \mu \mathrm{m}$, which was obtained with a $0.03 \%$ Ti content. A higher Ti con-

Table 1: Chemical compositions of A206 alloys before the grain refinement, in mass fractions ( $w / \%)$

Tabela 1: Kemijska sestava zlitin A206, pred udrobnjenjem zrn, v masnih deležih ( $w / \%)$

\begin{tabular}{|c|c|c|c|c|c|c|c|c|c|}
\hline \multirow{2}{*}{$\begin{array}{l}\text { Experiment } \\
\text { number }\end{array}$} & \multicolumn{9}{|c|}{ in mass fractions $(w / \%)$} \\
\hline & $\mathrm{Si}$ & $\mathrm{Fe}$ & $\mathrm{Cu}$ & $\mathrm{Mn}$ & $\mathrm{Mg}$ & $\mathrm{Zn}$ & B & $\mathrm{Ti}$ & $\mathrm{Al}$ \\
\hline 1 & 0.041 & 0.105 & 4.510 & 0.281 & 0.214 & 0.098 & 0.001 & 0.000 & bal. \\
\hline 2 & 0.039 & 0.107 & 4.610 & 0.353 & 0.199 & 0.084 & 0.002 & 0.007 & bal. \\
\hline
\end{tabular}

Table 2: Average grain size of the samples with different Ti contents

Tabela 2: Povprečna velikost zrn pri vzorcih z različno vsebnostjo Ti

\begin{tabular}{|c|c|c|c|c|c|c|c|c|c|}
\hline \multirow{2}{*}{$\mathrm{Ti}(w / \%)$} & Target & 0 & 0.01 & 0.02 & 0.03 & 0.05 & 0.1 & 0.2 & 0.3 \\
\cline { 2 - 22 } & Realized & 0 & 0.013 & 0.019 & 0.032 & 0.044 & 0.098 & 0.194 & 0.292 \\
\hline Average grain size $(\mu \mathrm{m})$ & 970 & 112 & 92 & 82 & 81 & 79 \\
\hline
\end{tabular}




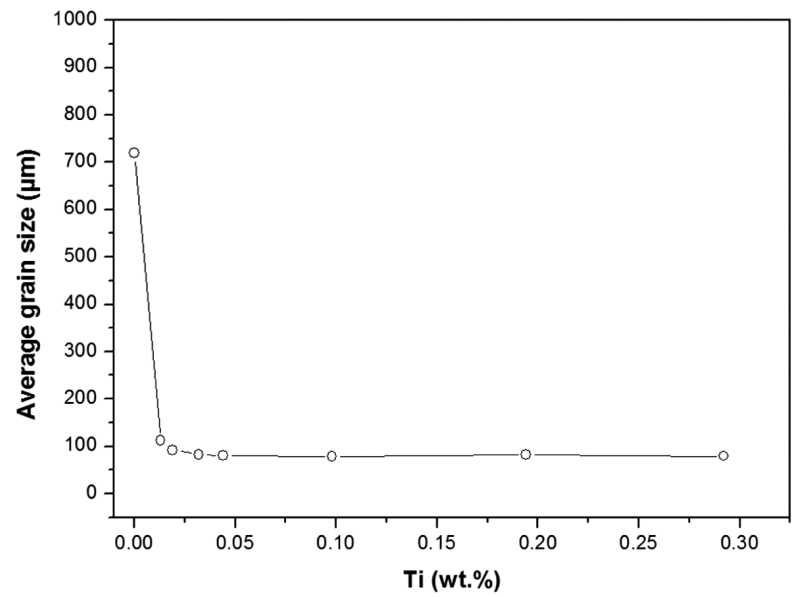

Figure 2: Effect of the Ti content on the grain size of the A206 alloy Slika 2: Vpliv vsebnosti Ti na velikost zrn zlitine A206

tent within the A206 alloy did not further reduce the grain size of the samples. These results are in good agreement with the previous work carried out by Sigworth and co-workers. ${ }^{3,7-8}$

The relationship between the titanium recovery and the microstructure is given in Figure 3. Figure 3a shows the microstructure of the sample obtained with no grainrefiner addition. The microstructure consists of coarse dendrites, heterogeneously distributed in equiaxed grains. Figure 3b shows a small addition of Ti, as low as a $0.01 \%$ mass fraction, which caused the grain refinement of the A206 alloy. However, a Ti content of up to $0.05 \%$ was found to be more effective for further reducing the average grain size of the alloy, as seen in Figure 3c. The microstructure obtained with a $0.3 \%$ mass fraction of Ti in the melt is shown in Figure 3d. It indicates that the increased amount of $\mathrm{Ti}$ no longer affected the reduction of the grain size of the A206 alloy used in this study.

The Al5Ti1B master alloy is an effective grain refiner of Al-Cu alloys as it increases the number of heterogeneous nucleation sites for achieving a finer equiaxed grain structure. ${ }^{10}$ Figure 3 clearly shows that a Ti content exceeding the mass fraction of $0.01 \%$ is adequate to turn

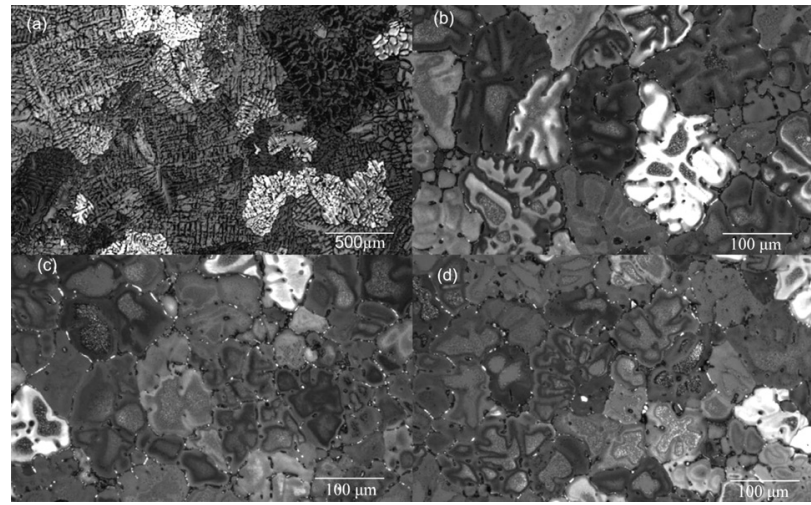

Figure 3: Microstructure of the A206 alloy with different Ti additions: a) $0 \%$ of mass fractions, b) $0.01 \%$ of mass fractions, c) $0.05 \%$ of mass fractions and d) $0.3 \%$ of mass fractions

Slika 3: Mikrostruktura zlitine A206 z različnimi dodatki Ti: a) $0 \%$ masnega deleža, b) $0,01 \%$ masnega deleža, c) 0,05 \% masnega deleža in d) $0,3 \%$ masnega deleža

the solidification morphology of the alloy from a fully dendritic to a globular or near-dendritic structure. Thus, the grain refinement of the A206 alloy by adding the Al5Ti1B master alloy can be expected to increase the mechanical properties of A206 castings via reducing the amount of solidification defects such as hot tearing, micro-shrinkage and micro-segregation. These results are in good agreement with the report from H. Kamali et al. ${ }^{5}$ who reported that Ti additions of $0.05-0.3 \%$ showed no significant effect on the grain size, although the minimum $\mathrm{Ti}$ mass fractions of $0.05 \%$ was necessary to eliminate the hot-tearing defects.

\subsection{Effects of the holding time and melt stirring on the grain size}

In the present study, possible effects of melt stirring during the holding period after the master-alloy addition were also investigated. Experiments were carried out with the castings from two different heats of stirred and non-stirred melts. Samples were cast in 30-min intervals throughout the 90-min holding time, during which the amount of $\mathrm{Ti}$ was fixed at around $0.05 \%$ of mass fractions.

Table 3: Effect of the holding time on the average grain size Tabela 3: Vpliv časa zadrževanja na povprečno velikost zrn

\begin{tabular}{|c|c|c|c|c|c|}
\hline $\begin{array}{c}\text { Liquid-metal } \\
\text { condition }\end{array}$ & $\begin{array}{l}\text { Holding time } \\
(\mathrm{min})\end{array}$ & $\begin{array}{l}\text { Ti recovery } \\
(w / \%)\end{array}$ & $\begin{array}{c}\text { B recovery } \\
(w / \%)\end{array}$ & $\mathrm{Ti}: \mathrm{B}$ ratio & $\begin{array}{l}\text { Average grain size } \\
(\mu \mathrm{m})\end{array}$ \\
\hline \multirow{4}{*}{$\begin{array}{c}\text { Heat } 1 \\
\text { Stirred melt }\end{array}$} & 0 & 0.049 & 0.009 & 5.4 & 84 \\
\hline & 30 & 0.046 & 0.008 & 5.8 & 84 \\
\hline & 60 & 0.047 & 0.008 & 5.9 & 85 \\
\hline & 90 & 0.048 & 0.009 & 5.3 & 84 \\
\hline \multirow{5}{*}{$\begin{array}{l}\text { Heat } 2 \\
\text { Non-stirred melt }\end{array}$} & 0 & 0.046 & 0.009 & 5.1 & 84 \\
\hline & 30 & 0.036 & 0.005 & 7.2 & 88 \\
\hline & 60 & 0.035 & 0.004 & 8.8 & 102 \\
\hline & 90 & 0.031 & 0.003 & 10.3 & 111 \\
\hline & $90 *$ & 0.048 & 0.009 & 5.3 & 85 \\
\hline
\end{tabular}

(90*) Stirring after $90 \mathrm{~min}$. 
A summary of the quantitative results obtained from the test samples throughout these experiments are shown in Table 3. Titanium and boron measured in the samples, cast with the stirred melt, show that both elements remained at almost their initial values during the 90-min holding time. Accordingly, the initial Ti:B ratio also remained constant, which was around 5:5. The average grain size of the stirred melt was about $85 \mu \mathrm{m}$ regardless of the holding time. These results emphasise the fact that the refining efficiency of the Al5Ti1B type master alloy is consisted, at least during the 90-min holding time, even with the Ti recovery as small as $0.05 \%$ of mass fractions of $\mathrm{Ti}$ in the A206 alloy. On the other hand, the results obtained for the non-stirred melt reveal that both titanium and boron recovery decreased with the increasing holding time. Interestingly, the diminution in boron was faster compared to titanium, especially in the first $30 \mathrm{~min}$ of the holding time, for the non-stirred melt. Therefore, the measured Ti:B ratio shows a continuous increase as the period of the holding time increases.

In Table 3, the average measured grain size for the samples of the non-stirred melt also shows a consisted increase with the holding time. This is associated with the diminishing of the $\mathrm{Ti}$ and $\mathrm{B}$ recovery and the ever increasing Ti:B ratio with the increasing holding time for the non-stirred heat. It is also obvious from Table 3 that
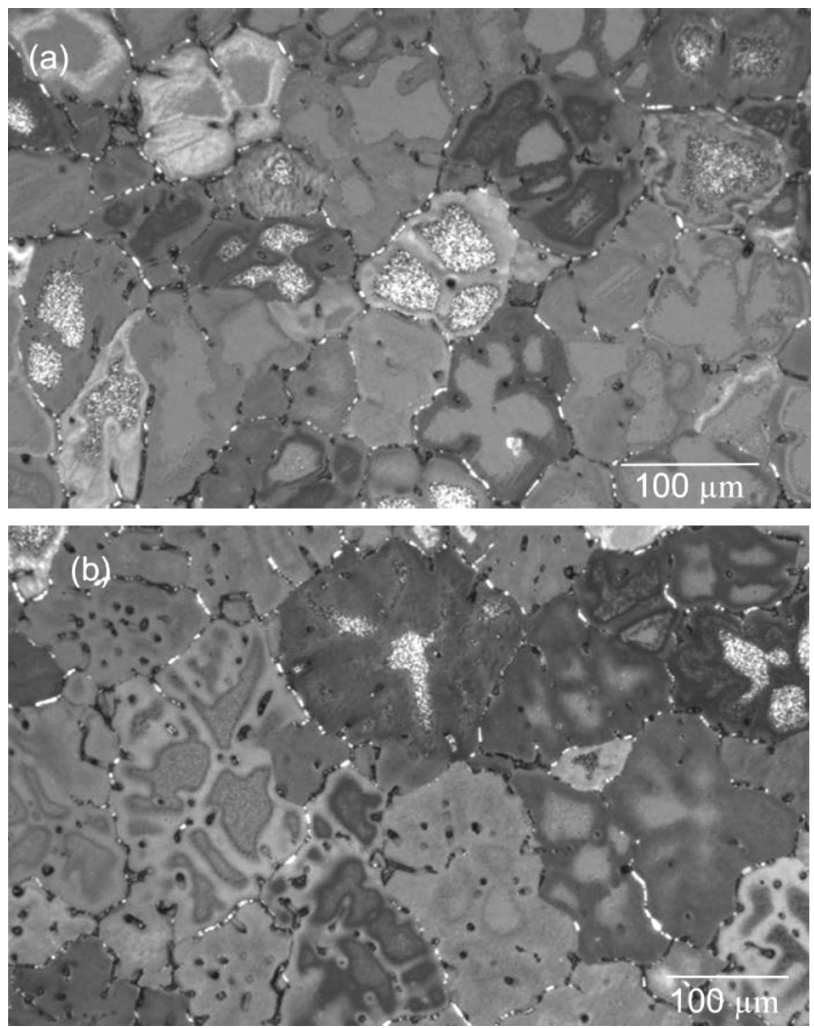

Figure 4: Microstructures of Alcan test samples after a $90 \mathrm{~min}$ holding time and an Al5Ti1B master-alloy addition. Samples were cast from: a) continuously stirred melt and b) non-stirred melt.

Slika 4: Mikrostruktura Alcan preizkušancev po 90 min zadrževanju po dodatku predzlitine Al5Ti1B. Vzorci so bili uliti iz: a) kontinuirno mešane taline in b) taline brez mešanja. an immediate stirring action followed by a 90 -min holding time facilitated the $\mathrm{Ti}$ and $\mathrm{B}$ levels as well as the Ti:B ratio to remain almost at their initial values. This also caused a similar consequence in the measured grain size. These results are in good agreement with a number of previous studies on Al-Cu alloys. Grain-refining studies on non-stirred melts were concluded so that the grain size increased continuously with the increasing holding time; ${ }^{11-12,16}$ however, it began to decrease when the stirring action was resumed. ${ }^{16}$

The phenomenon of decreasing $\mathrm{Ti}$ and $\mathrm{B}$ with the increasing holding time in the non-stirred A206 alloy can be attributed to the settling of $\mathrm{TiB}_{2}$. This compound has been widely accepted as one of the potential nucleation sites during the solidification of aluminium. ${ }^{19-22}$ Since the density of a solid $\mathrm{TiB}_{2}$ compound is higher (4.48 $\left.\mathrm{g} / \mathrm{cm}^{3}\right)^{17}$ than that of the liquid A206 alloy $\left(2.78 \mathrm{~g} / \mathrm{cm}^{3}\right)$, it is quite probable that some potential $\mathrm{TiB}_{2}$ nuclei are disqualified because they sink to the bottom of the crucible as the holding time increases.

The microstructures representing the Alcan test samples obtained from the heats after the 90-min holding time are shown in Figures $\mathbf{4 a}$ and $\mathbf{4 b}$. A comparison of the two microstructures provides an explanation of the difference between the stirred and the non-stirred melts. The larger grain size for the non-stirred melt in Figure $4 \mathbf{b}$ can be associated with a weaker grain-refining action of the master alloy during the 90-min holding. This can also be related to the fading of the potential nuclei probably due to the gravity action of the $\mathrm{TiB}_{2}$ compound. ${ }^{18}$

\section{CONCLUSIONS}

The grain-refining effects of the Al5Ti1B rod-type master alloy on a commercial A206 alloy with different addition levels were studied. The effects of the holding time under stirring and no-stirring conditions were also studied. From the experimental results, the following conclusions can be drawn:

1) Different amounts of titanium recovery ranging from 0.01 to 0.3 were formed in the A206 alloys. Measurements showed that the grain size of the Alcan test samples decreased dramatically with an addition of the A15Ti1B master alloy regardless of the titanium recovery.

2) The smallest average grain size of the A206 alloy was $82 \mu \mathrm{m}$, achieved with a $0.03 \%$ of mass fraction of Ti recovery in the melt. Increasing the Ti recovery up to a $0.3 \%$ of mass fractions did not result in a further decrease in the grain size of the A206 alloy.

3) Grain-size measurements for two different heats showed that the average initial grain size of the samples increased from $84 \mu \mathrm{m}$ to $111 \mu \mathrm{m}$ at the end of the 90-min holding time for the non-stirred liquid. However, a constant grain size was achieved for the stirred melt throughout the holding period.

4) The results obtained for the non-stirred melt revealed that both titanium and boron recovery decreased with 
the increasing holding time. During the holding period, the diminution in boron was larger compared to titanium, as measured on the cast samples. This was attributed to the formation of $\mathrm{a} \mathrm{TiB}_{2}$ compound in the melt, which is widely accepted as a heterogeneous nucleation site for aluminium. Since the density of $\mathrm{TiB}_{2}$ is higher than that of the liquid A206 alloy, the compound tends to settle in the non-stirred melt, which may be the reason for the fading of the grainrefining efficiency as the holding time increases.

5) The refining efficiency of the Al5Ti1B-type master alloy can be stimulated via re-stirring the melt. The results showed that an immediate stirring action followed by a 90-min holding time reverted Ti and B and also the Ti:B ratio almost to their initial conditions. The Alcan test samples of the re-stirred melt also showed a well-refined grain structure.

\section{Acknowledgements}

Authors thank Mr. Ahmet Cevdet Altun at Altun Döküm A.Ş., Konya, Turkey, for the casting experiments carried out at the premises of the company.

\section{REFERENCES}

${ }^{1}$ H. K. Kamga, D. Larouche, M. Bournane, A. Rahem, Mechanical properties of aluminium-copper B206 alloys with iron and silicon additions, International Journal of Cast Metals Research, 25 (2012), 15-25, doi:10.1179/1743133610Y.0000000012

${ }^{2}$ H. K. Kamga, D. Larouche, M. Bournane, A. Rahem, Hot tearing of aluminum-copper B206 alloys with iron and silicon additions, Materials Science and Engineering, 527A (2010), 7413-7423, doi:10.1016/j.msea.2010.08.025

${ }^{3}$ G. K. Sigworth, F. DeHart, Recent developments in the high strength aluminum-copper casting alloy A206, AFS Transactions, 111 (2003), 341-354

${ }^{4}$ T. Wang, T. Gao, P. Zhang, J. Nie, X. Liu, Influence of a new kind of $\mathrm{Al}-\mathrm{Ti}-\mathrm{C}$ master alloy on the microstructure and mechanical properties of Al-5Cu alloy, Journal of Alloys and Compounds, 589 (2014), 19-24, doi:10.1016/j.jallcom.2013.11.187

${ }^{5}$ H. Kamali, M. Emamy, A. Razaghian, The influence of Ti on the microstructure and tensile properties of cast $\mathrm{Al}-4.5 \mathrm{Cu}-0.3 \mathrm{Mg}$ alloy, Materials Science and Engineering A, 590 (2014), 161-167, doi:10.1016/j.msea.2013.10.032

${ }^{6}$ Y. D. Kwon, Z. H. Lee, The effect of grain refining and oxide inclusion on the fluidity of Al-4.5 $\mathrm{Cu}-0.6 \mathrm{Mn}$ and A356 alloys, Materials Science and Engineering A, 360 (2003), 372-376, doi:10.1016/ S0921-5093(03)00504-5
${ }^{7}$ G. K. Sigworth, Improved hot crack resistance, U.S. Patent US6, 645, 321, 11. 11. 2003

${ }^{8}$ G. K. Sigworth, Providing melt of aluminum base alloy, maintaining dissolved titanium in range of 0.005 to $0.05 \mathrm{wt} \%$ to improve resistance of alloy to hot cracking, adding nucleating agent selected from metal carbides, aluminides, borides, solidifying, U.S. Patent US6, 368, 427, 9. 4. 2002

${ }^{9}$ G. K. Sigworth, T. A. Kuhn, Grain refinement of aluminum casting alloys, AFS Transactions, 115 (2007), 1-12

${ }^{10}$ G. P. Jones, J. Pearson, Factors affecting the grain-refinement of aluminum using titanium and boron additives, Metallurgical Transactions B. 7 (1976), 223-234, doi:10.1007/BF02654921

${ }^{11}$ K. Sato, M. C. Flemnigs, Grain refining of Al-4.5 Cu alloy by adding an Al-30TiC master alloy, Metallurgical and Materials Transactions A, 29 (1998), 1707-1710, doi:10.1007/s11661-998-0093-2

${ }^{12}$ P. Cooper, A. Barber, Review of the latest developments and best use of grain refiners, 2th International Melt Quality Workshop, Prague, Czech Republic 2003

${ }^{13}$ Alcan AA206 Primary Foundry Alloys 206.2, A206.2 and B206.2, Alcan Primary Products Corporation Inc., Robards, KY, USA 2004

${ }^{14}$ S. Li, K. Sadayappan, D. Apelian, Role of Grain Refinement in the Hot Tearing of Cast Al-Cu Alloy, Metallurgical and Materials Transactions B, 44 (2013), 614-623, doi:10.1007/s11663-013-9801-4

${ }^{15}$ M. A. Kearns, S. R. Thistlewaite, P. S. Cooper, In W. Hale (Ed.), Light Metals TMS, Warrendale 1996

${ }^{16}$ H. Li, T. Sritharan, Y. M. Lam, N. Y.Leng, Effects of processing parameters on the performance of $\mathrm{Al}$ grain refinement master alloys Al-Ti and Al-B in small ingots, Journal of Materials Processing Technology, 66 (1997), 253-257, doi:10.1016/S0924-0136(96) 02536-8

${ }^{17}$ L. Zhou, Z. Fan, Effect of Free Ti on Grain Refinement of Aluminium Inoculated with Potent $\mathrm{TiB}_{2}$ Particles, Materials Science Forum, 790-791 (2014), 155-160, doi:10.4028/www.scientific.net/ MSF.790-791.155

${ }^{18}$ P. S. Mohanty, J. E. Gruzleski, Mechanism of grain refinement in aluminium, Acta Metallurgica et Materialia, 43 (1995) 5, 2001-2012, doi:10.1016/0956-7151(94)00405-7

${ }^{19}$ P. S. Mohanty, J. E. Gruzleski, Grain refinement mechanisms of hypoeutectic Al-Si alloys, Acta Materialia, 44 (1996) 9, 3749-3760, doi:10.1016/1359-6454(96)00021-3

${ }^{20}$ C. Wang, M. Wang, B. Yu, D. Chen, P. Qin, M. Feng, Q. Dai, The grain refinement behaviour of $\mathrm{TiB}_{2}$ particles prepared with in situ technology, Materials Science and Engineering A, 459 (2007), 238-243, doi:10.1016/j.msea.2007.01.013

${ }^{21}$ Z. Fan, Y. Wang, Y. Zhang, T. Qin, X. R. Zhou, G. E. Thompson, T. Pennycook, T. Hashimoto, Grain refining mechanism in the Al/Al-Ti-B system, Acta Materialia, 84 (2015), 292-304, doi:10.1016/j.actamat.2014.10.055

${ }^{22}$ X. Wang, Z. Liu, W. Dai, Q. Han, On the Understanding of Aluminum Grain Refinement by Al-Ti-B Type Master Alloys, Metallurgical and Materials Transactions B, (2014), doi:10.1007/s11663014-0252-3 